\title{
Curved rotary module for modular construction of motion structures
}

Jozef Svetlík(SK) jozef.svetlik@tuke.sk

Peter Demeč(SK) peter.demec@tuke.sk

\section{BIOGRAPHICAL NOTES}

Jozef Svetlík, Ing. PhD. (born in 1977) assistant professor at the Department of Manufacturing Engineering and Robotics (since 2003) at the Faculty of Mechanical Engineering in TU Košice (SjF, TUKE). Graduate TUKE SjF 2000, scientific degree of Doctor of Philosophy (PhD) defended at Technical University of Košice in 2004. Internal PhD. student SjF TUKE (2000-2003). Member of the editorial board of "Journal of Applied Statistics. Research interests of construction machinery and modular robotics. Co-author of the script "modules for the construction of production machinery" and "Robotics - Technical equipment for automated workplaces: inter-operational handling. Winner of "Siemens Excellence Award 2004" for the dissertation. The holder of an honorary recognition of the International Engineering Fair 2003 in Nitra Agrokomplex for "intelligent modular assembly system". Team member "SjF Tuke robotics", which is several times European champion and world champion from 2010 in robotic soccer. Author of a utility model "rotary module for modular construction machinery" and patent "contactless transmission of electrical power for modular machines" (in the approval process). Author of over 60 scientific and professional articles in journals and contributions to scientific and professional conferences.

Peter Demeč, prof. Ing. PhD. (born in 1952) professor of Production machinery and equipment (since 2003) at the Faculty of Mechanical Engineering TU of Košice (SjF, TUKE). Graduate SjF TUKE in 1975, scientific degree Candidate of Sciences (CSc / PhD.) defended the STU in Bratislava in 1984, Associate Professor of habilitated SjF TUKE 1994. SjF TUKE prodean (1993-1996), Head of Department of Manufacturing Technology (1997-2002), Deputy Head of the Department of Production Systems and Robotics (2003-present). Member of scientific advice SjF TUKE, Faculty of Environmental and Manufacturing Technology University in Zvolen, Faculty of Special Technology and University of Alexander Dubček in Trenčín, a member of the Society for machine tools, the Czech Republic, Club President of the Slovak Association of Mechanical Engineers for SjF TUKE, Member of Editorial Board, and MM Science Journal Technologist. Research interests of construction, virtual prototyping, and precision machine tools. Author of the memoir "The accuracy of machine tools and its mathematical modeling" (Košice: Vienala 2001) and over 130 scientific and professional articles in journals and contributions to scientific and professional conferences.

\section{KEY WORDS}

Modular Machine, Rotation Module, Robotic Manipulator, Curved Rotary Module, Modular Construction, Robot Workspace, Serial Robot

\section{ABSTRACT}

The article deals with the mechanics of modular machines and examines in detail the parameters of the principle of joining newly designed curved rotary modules into 
homogeneous serial kinematical chain with five degrees of freedom of movement. The result of analysis is generated workspace built on the basis of $60^{\circ}$ curved rotary module with unlimited rotation for a serial kinematical structure with homogeneous 5DOF.

\section{INTRODUCTION}

The idea of modular principle of machines is not new [6]. In the past there have been many creative and innovative ideas from which the amount of time is transformed into a real functioning machine. In the field of motion structures with modular serial construction, there are some innovative solutions to many well-known and unknown companies, for example.: SCHUNK, Epson, Yamaha. These concepts give a chance to build machines for the handling, processing and other tasks as seen in Fig. 1.

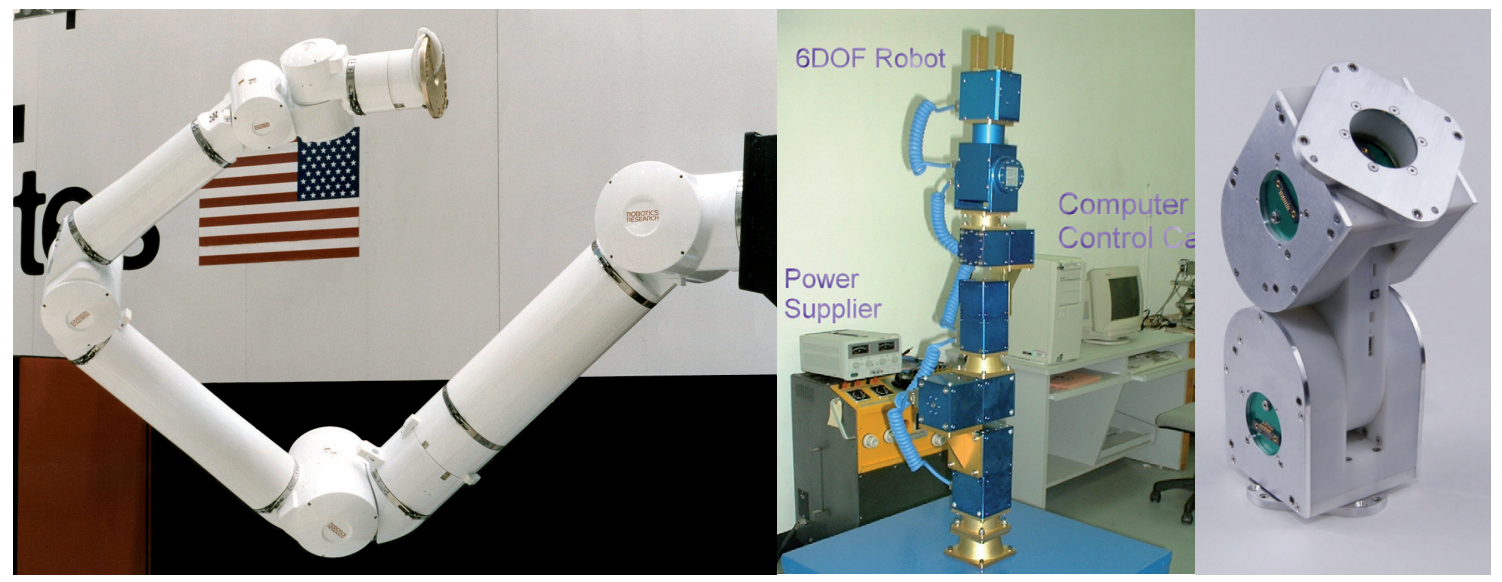

Fig. 12 Modular serial structures

Known modular systems also offer a range of modular motion units. These modules are characterized by different attributes, parameters and sizes. Modules can be translational, rotational, and other rare cases. The main weaknesses of these modules include the limitation of rotational movement and greater complexity of design.

From these facts suggest limiting it to the prescribed limits of the range of motion (rotation in the range max. 270 degrees, translational motion in the range of $350 \mathrm{~mm}$, and so on). The resulting movement possibilities of cinematic chain composed of these modules have a limited range of rotational movement. This eliminates the shortcomings hereinafter referred rotation module for the construction of modular machines.

\section{Principle of Design Solutions}

Rotation module, designed for modular construction machinery, allows merge these modules and the creation of kinematic chain with theory of any number of degrees of freedom of movement, able to perform controlled motion [1]. Its internal structure consists of a body, interlink and clamp- ing plate, which performs a rotational movement over the body, as seen in Figs. 2, 3. In the body of a rotary module is stored servomotor and reducer. Servomotor is equipped with incremental encoder and an electromagnetic brake.

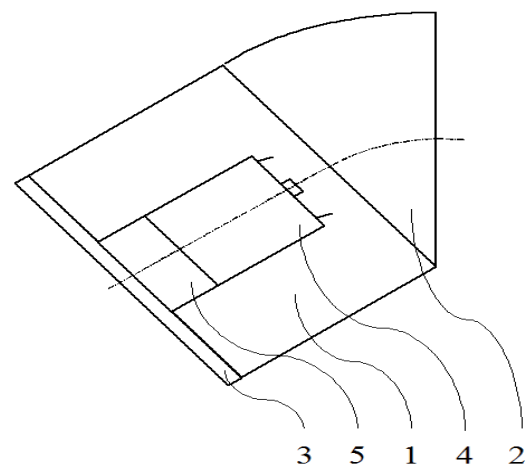

Fig. 2 Sketch the basic layout of the internal rotation module

Clamping plate of rotation module is attached to the body through a rotary motion tie of one degree of freedom of movement and it is located on the clamping mechanism for connecting interlink 
to the next module (modules in the chain). This rotary motion linkage is unlimited range of motion [11]. Interlink of rotation module is geometrically curved and includes a bayonet fixing mechanism for connecting of clamping plate of the previous module (modules in the chain). Angle of curvature determines the scope and characteristics of the working space of the modular machine assembled from these modules.

Homogeneous kinematic structure of a modular concept consists of several identical or identical type (eg. size or curvature of the diverging) rotary motion modules [12].

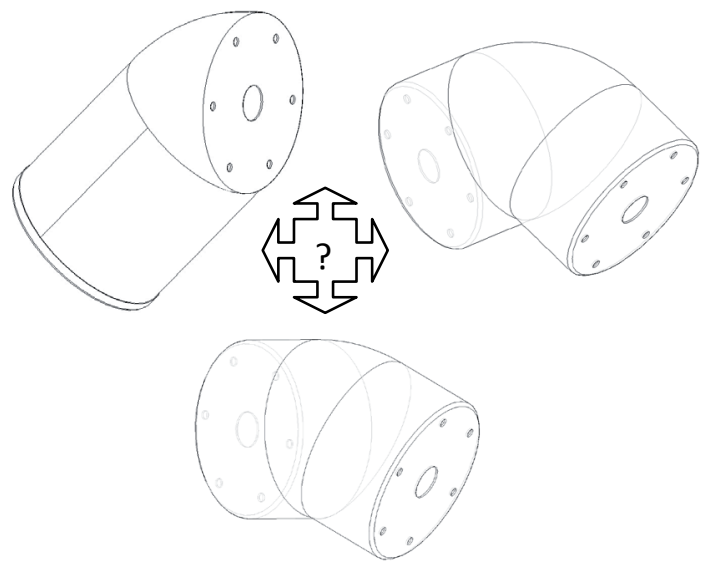

Fig. 3 Modification of 3D models of a separate rotary module of varying degrees of curvature

Links between all internal parts of the module and also between the individual modules are fixed (except rotary links between the body and clamping plate), sufficiently rigid and unable to pass the required mechanical load. Communication equipment intended for control are proposed as a wireless, eg.: WiFi, Bluetooth and so on. Electronic communications modules with accessories should be positioned into the body of the module. Connection of individual modules should be realize in terms of flexibility by bayonet method.

Example of 3D display modular manipulator with 6 degrees of freedom of movement is shown in Fig. 4, which are used to build basic rotary modules. This series homogenous structure is characterized by its simplicity and not the most appropriate reachability within your workspace. To achieve the desired position to be extensive rotationing of many modules, which is relatively energy consuming.
Example of 3D display modular manipulator with 6 degrees of freedom of movement is shown in Fig. 5, when is used the extension part [9]. This part serves to increase the reach of kinematic chain and has no internal drive system. It is inserted between the modules and in this way, adjusts the characteristics of the working space and also reachability positioning member in the end of it. Except the extension member are also used rotating different modules with varying degrees of curvature. This method achieves a high flexibility and variability of working space and reachability of location is a function of mutual selection and arrangement of appropriate modules and extension parts.

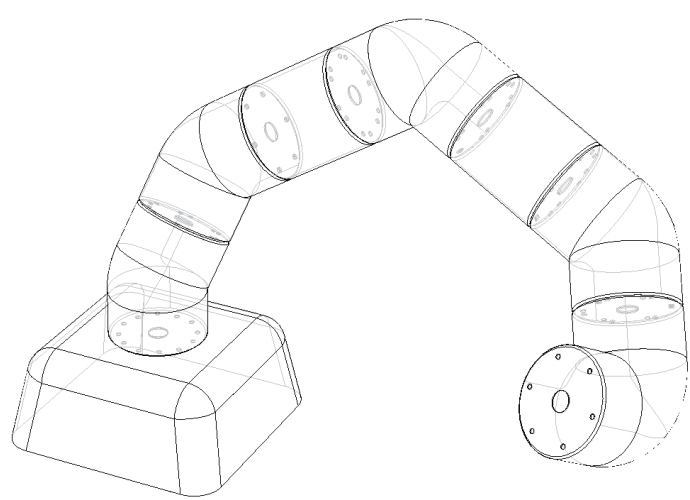

Fig. 4 3D model of the modular machine, assembled from rotary motional basic modules, with 6 degrees of freedom of movement

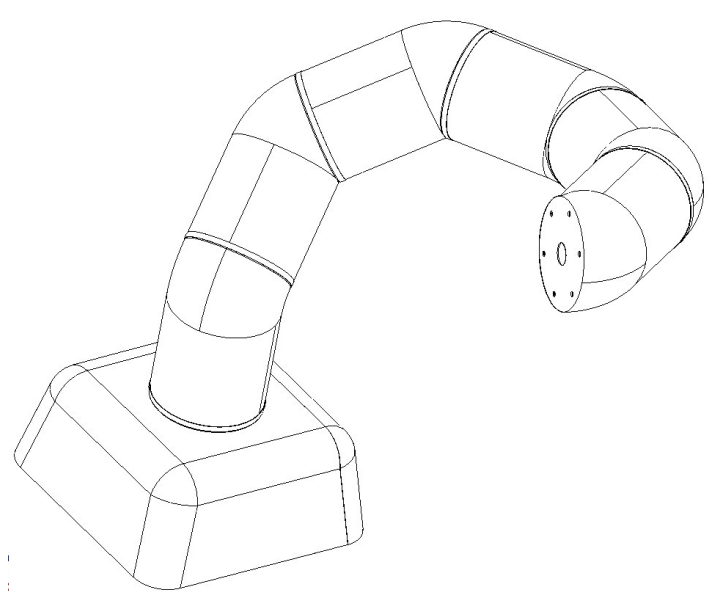

Fig. 5 3D model with a modular machine using an extension part and adapted the basic modules with 6DOF 


\section{Mathematical Description of Structure}

For the mathematical description of a serial kinematic chain is best to use Denavit-Hartenberg principle of deployment of joint chain to the coordinate systems [2]. This deployment will achieve particulate transformation matrices (1). This transformation matrix "Ab0" describes the position and rotation of the first couple coordinate systems, thus the current position of the base "b" and the first module "0" in Fig. 6, where q1 and q5 are common variables. In our case, the steering angles of rotary modules and take their values in the interval $(0,2 \pi)$. Variables $l \times 1$ and $l \times 2$ represent distance of local coordinate systems according to the principle of D-H principle. Variable "a" represent the angle of curvature of the module used in this case was used $60^{\circ}$ angle. Further transformation matrices in order of the other members of the kinematic chain are analogous to the shape and functions are gradually variables q2 and q5. In order to get the overall transformation matrix is necessary transformation matrix between neighboring coordinate system multiplied "Ab0" and "A01", resulting in a total transformation matrix of great complexity. Relationship (2) reflects the partial transformation matrix between the base "b" and the second movable member in order-rotating module, "1". After multiplying all the sub-transformation matrices of type " $\mathrm{A}$ " there
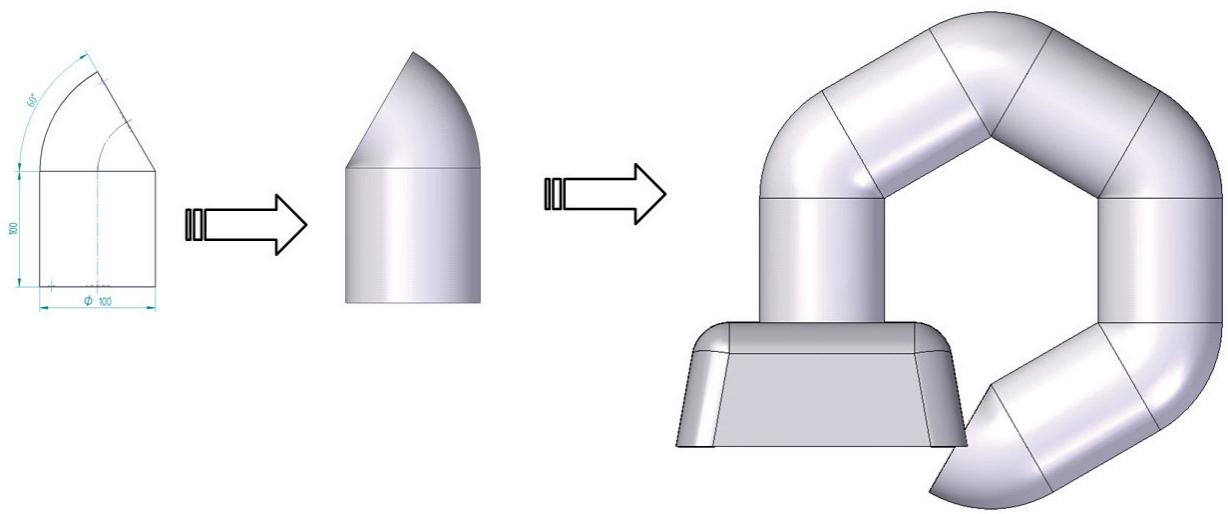

Fig. 6 3Composition of homogeneous serial kinematical structures with 5DOF

$A_{b 0}\left(q_{1}, q_{2}, q_{3}, q_{4}, q_{5}, q_{6}\right)=\left(\begin{array}{cccc}\cos q_{1} & -\sin q_{1} \cdot \cos a & \sin q_{1} \cdot \sin a & l_{x 1} \cdot \cos q_{1} \\ \sin q_{1} & \cos q_{1} \cdot \cos a & -\cos q_{1} \cdot \sin a & l_{x 1} \cdot \sin q_{1} \\ 0 & \sin a & \cos a & l_{x 2} \\ 0 & 0 & 0 & 1\end{array}\right)$

$T_{b 1}\left(q_{1}, q_{2}, q_{3}, q_{4}, q_{5}, q_{6}\right)=A_{b 0}\left(q_{1}, q_{2}, q_{3}, q_{4}, q_{5}, q_{6}\right) \cdot A_{01}\left(q_{1}, q_{2}, q_{3}, q_{4}, q_{5}, q_{6}\right)=$

$\left(\begin{array}{ccccc}\frac{3 \cdot \cos \left(q_{1}-q_{2}\right)}{4}+\frac{\cos \left(q_{1}+q_{2}\right)}{4} & \frac{3 \cdot \sin q_{1}}{4}+\frac{\cos q_{1} \cdot \sin q_{2}}{2}-\frac{\cos q_{2} \cdot \sin q_{1}}{4} & \frac{\sqrt{3} \cdot \cos q_{1} \cdot \sin q_{2}}{2}-\frac{\sqrt{3} \cdot \sin q_{1}}{4}-\frac{\sqrt{3} \cdot \cos q_{2} \cdot \sin q_{1}}{4} & 150 \cdot \cos q_{1}+75 \cdot \sin q_{1}+150 \cdot \cos q_{1} \cdot \cos q_{2}+75 \cdot \sin q_{1} \cdot \sin q_{2} \\ \frac{3 \cdot \sin \left(q_{1}-q_{2}\right)}{4}+\frac{\sin \left(q_{1}+q_{2}\right)}{4} & \frac{\cos q_{1} \cdot \cos q_{2}}{4}-\frac{3 \cdot \cos q_{1}}{4}+\frac{\sin q_{1} \cdot \sin q_{2}}{2} & \frac{\sqrt{3} \cdot \cos q_{1}}{2}+\frac{\sqrt{3} \cdot \cos q_{1} \cdot \cos q_{2}}{4}+\frac{\sqrt{3} \cdot \sin q_{1} \cdot \sin q_{2}}{4} & 150 \cdot \sin q_{1}-75 \cdot \cos q_{1}-74 \cdot \cos q_{1} \cdot \sin q_{2}+150 \cdot \cos q_{2} \cdot \sin q_{1} \\ \frac{\sqrt{3} \cdot \sin q_{2}}{2} & \frac{\sqrt{3} \cdot\left(\cos q_{2}+1\right)}{4} & \frac{1}{4}-\frac{3 \cdot \cos q_{2}}{4} & 25 \cdot \sqrt{3} \cdot\left(3 \cdot \sin q_{2}+1\right) \\ 0 & 0 & 1\end{array}\right)$

\section{Identification of Workspace}

To identify the shape and scope of workspace was necessary to define transformation matrices in a MathCAD program $[3,8]$ and also define the geometrical parameters: the curvature module $\mathrm{a}=\pi / 3 \mathrm{rad}$, module length $l 1=100 \mathrm{~mm}$, width mod- ule $l 2=100 \mathrm{~mm}$. The distance between the coordinate system is defined as a variable Lx1 and Lx2 $(3,4)$. It is necessary to define the scope of the local variable q1...q5 is from the interval $(0,2 \pi)$ and the step number is $1 \frac{1}{2} \mathrm{rad}$. 

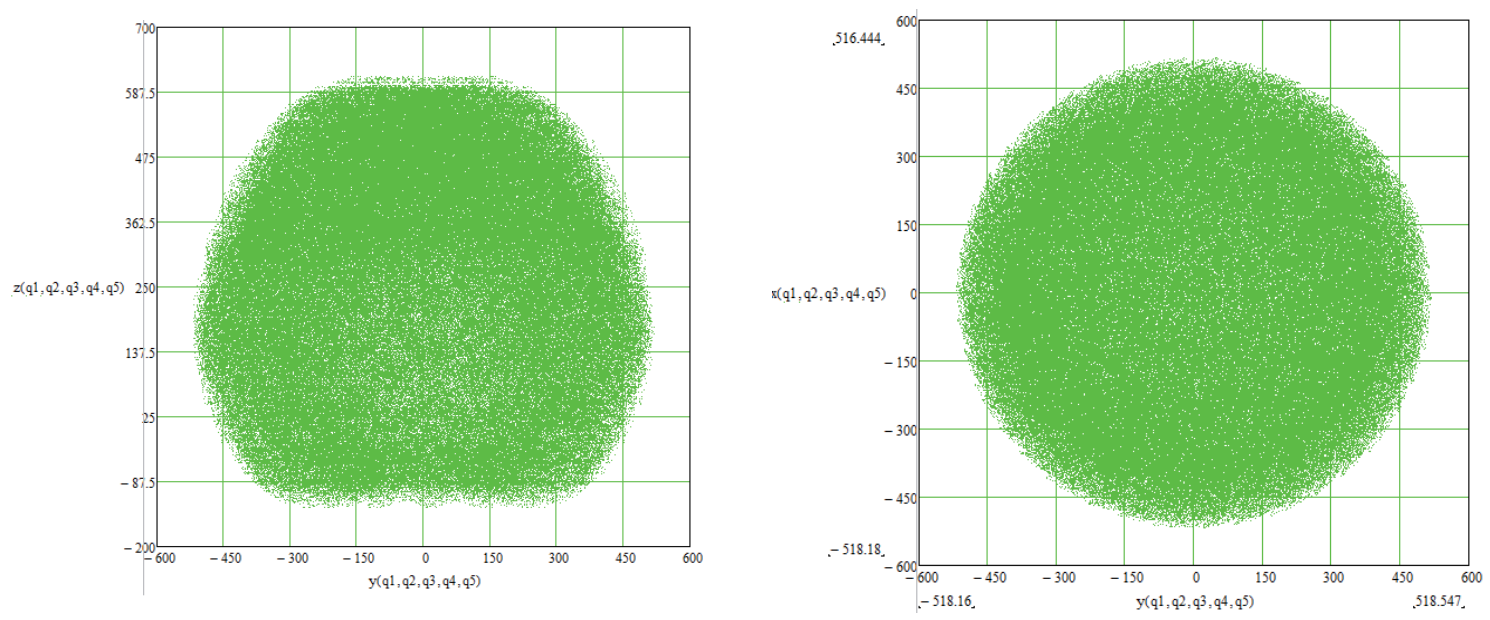

Fig. 7 Workspace of modular serial kinematic structures with 5DOF the curvature of the building module $60^{\circ}$

$$
\begin{aligned}
& l_{x 1}=0,5 \cdot l_{1} \cdot(1-\cos a) \\
& l_{x 2}=l_{2}+\frac{l_{1} \cdot \sin a}{2}
\end{aligned}
$$

Formularization of the overall transformation matrix and the gradual substitution of the general variables q1 until q5 the specified steps to get around 33000 points. These points represent the final position in the end coordinate system rotating module. Their display in a suitably chosen Cartesian coordinate system we will likely shape, size and scope of workspace. Workspace of homogeneous serial kinematic structure of Fig. 6 is reproduced in Fig. 7.

\section{Conclusion}

The overall result of the described technical solution is a modular system for the building of modular machines assembled from identical or identical type (eg diverging of size or curvature) rotary motion units with unlimited rotation range of motion [7]. It is necessary to make more extensive analysis and find the best angle of curvature of the building module. This angle should be provide for widest possible range of workspace and also a good reachability of desired point in this workspace. On the other side should be provide the safe operation of that in any position of the kinematic chain can happen to self-collision kinematic structure [4]. It is probable that the varying degree of freedom of movement should always choose a different angle of curvature of the basic module [5]. Similarly it is probable that application-specific angle of curvature may be appropriate basic module other than that which is derived simulation in virtual terms $[10,13]$.

\section{References}

[1] Svetlík, J., Demeč, P., Turisová, R., Rotačný modul na stavbu modulárnych strojov: úžitkový vzor: prihláška č. 99-2010, Banská Bystrica: ÚPV SR, 2010. $12 \mathrm{~s}$

[2] Mostýn V., Skařupa J., Teorie prúmyslových robotú, In: Vienala pre Edíciu vedeckej a odbornej literatúry Strojníckej fakulty TU V Košiciach, 146s, 2000, ISBN 80-88922-35-6

[3] Krehel,, R., Dobránsky, J., Uplatnenie simulačného systému $v$ procese experimentálneho merania, 2009. In: Jemná mechanika a optika., Vol. 54, no. 11-12, p. 329-331., ISSN 0447-6441

[4] Baron, P., Kočiško, M: Aplikácia počítačovej podpory katastra rizík technických zariadení. In: Zborník z vedeckej konferencie Nové smery vo výrobných technológiách, FVT Prešov, 2004, s. 410 - 413, ISBN 80-8073-136-5

[5] Khouri, S., Kyselová, K., Al-Zabidi, D.: Restructuring an enterprise by implementing a complex information system as a tool for securing its further prosperity, 2009. In: Ekonomika ir vadyba: aktualijos ir perspektyvos., Vol. 14, no. 1, p. 152-158., ISSN 1648-9098

[6] Svetlík, J., Fedorčáková, M.: Progresívne typy robotov. In: Transfer inovácií. č. 11, SjF TU v 
Košiciach, 2008, str. 216-218, ISSN 1337-7094

[7] Lešková, A., Švač, V.: Aplikácia modulových stavebnicových systémov pri realizácii skúšobných stendov. In: Transfer inovácií: Špecializovaná publ., vedecko-technické výstupy grantových úloh. Košice: TU-SjF, 2003, s. 18-19

[8] Kočiško, M: Výskum v oblasti počítačovej podpory výrobných technológií. In: Strojárstvo, Media/ST, Žilina, 5/2007, s.141, ISSN 1335-2938

[9] Marcinčin, J. N., Zajac, J., Kočiško, M., Baron, P.: Solid Edge v19+v20, FVTTU Prešov, 2008, 312 s., ISBN 978-80-553-0050-4

[10] Šebo, J., Fedorčáková, M., Jurčišin, R.: Basic indicators of measuring productivity and their application on machinery production orders, In: Intercathedra: Annual scientific bulletin of plant- economic department of the european technology university studies. no. 2009, str. 132-136, ISSN 1640-3622

[11] Dobránsky, J.: Automatizácia procesu dopravy vstupnej suroviny do linky $v$ technológii balenia tavených syrov. In: Automation in production planning and manufacturing, SjF TU Žilina, 2006, s. 27-32, ISBN 80-8070-537-2

[12] Fedorčáková, M.: Logistické racionalizačné technológie, In.: Inovatívne projektovanie demontážnych procesov a systémov, zborník študijných materiálov 2009, TU v Košiciach, 978-80-553-0275-1

[13] Naščáková, J., et al.: Appcom as a flexible industry solution for managing modern IT infrastructure, In: Annals of MTeM for 2007 and proceedings of the 8th international conference Modern Technologies in Manufacturing., Cluj-Napoca: MTeM, 2007, p. 299-302, ISBN 9739087833

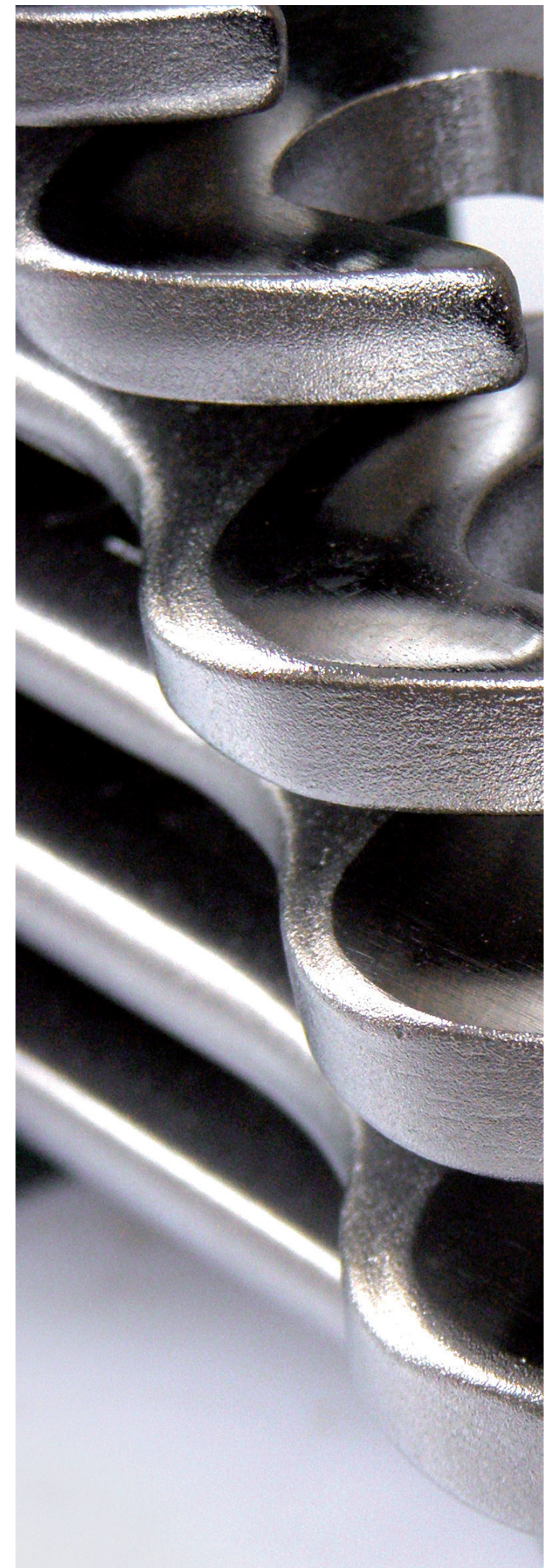

